NBER WORKING PAPER SERIES

\title{
FETAL MALNUTRITION AND ACADEMIC SUCCESS: EVIDENCE FROM MUSLIM IMMIGRANTS IN DENMARK
}

\author{
Jane Greve \\ Marie Louise Schultz-Nielsen \\ Erdal Tekin \\ Working Paper 21545 \\ http://www.nber.org/papers/w21545
}

\author{
NATIONAL BUREAU OF ECONOMIC RESEARCH \\ 1050 Massachusetts Avenue \\ Cambridge, MA 02138 \\ September 2015
}

The views expressed herein are those of the authors and do not necessarily reflect the views of the National Bureau of Economic Research. This research is supported by a grant (12-125309) from the Danish Council for Independent Research. Erdal Tekin also gratefully acknowledges support from the Gary and Stacey Jacobs Fellowship. The authors thank Janet Currie, Daniel Rees, and Ezra Susser for their helpful comments and suggestions. The authors are solely responsible for any views expressed.

NBER working papers are circulated for discussion and comment purposes. They have not been peerreviewed or been subject to the review by the NBER Board of Directors that accompanies official NBER publications.

(C) 2015 by Jane Greve, Marie Louise Schultz-Nielsen, and Erdal Tekin. All rights reserved. Short sections of text, not to exceed two paragraphs, may be quoted without explicit permission provided that full credit, including $(\odot)$ notice, is given to the source. 
Fetal Malnutrition And Academic Success: Evidence From Muslim Immigrants In Denmark Jane Greve, Marie Louise Schultz-Nielsen, and Erdal Tekin

NBER Working Paper No. 21545

September 2015

JEL No. I12,I14,I24,J15

\begin{abstract}
$\underline{\text { ABSTRACT }}$
This paper examines the impact of potential fetal malnutrition on the academic proficiency of Muslim students in Denmark. We account for the endogeneity of fetal malnutrition by using the exposure to the month of Ramadan during time in utero as a natural experiment, under the assumption that some Muslim women might have fasted during Ramadan when they were pregnant. In some of our specifications, we use a sample of students from predominantly non-Muslim countries as an additional control group to address potential seasonality in cognitive outcomes in a difference-in-differences framework. Our outcome measures are the standardized test scores from the national exams on the subjects of Danish, English, Math, and Science administered by the Danish Ministry of Education. Our results indicate that fetal exposure to Ramadan has a negative impact on the achievement scores of Muslim students, especially females. Our analysis further reveals that most of these effects are concentrated on the children with low socioeconomic status (SES) background. These results indicate that fetal insults such as exposure to malnutrition may not only hamper the cognitive development of children subject to such conditions, but it may also complicate the efforts of policy-makers in improving the human capital, health, and labor market outcomes of low-SES individuals. Our findings highlight the importance of interventions designed to help economically disadvantaged women during pregnancy.
\end{abstract}

Jane Greve

KORA, the Danish Institute for

Local and Regional Government Research

Købmagergade 22

DK-1150 København K

Denmark

JaGr@kora.dk

Marie Louise Schultz-Nielsen

Rockwool Foundation Research Unit

Sölvgade 10, 2. tv.

1307 Copenhagen K

Denmark

and IZA

mls@rff.dk

\section{Erdal Tekin}

School of Public Affairs

American University

4400 Massachusetts Avenue NW

Washington, DC 20016-8070

and IZA

and also NBER

tekin@american.edu 


\section{Introduction}

Substantial research has established that early years of life is a profoundly important period, during which environmental influences can have significant and longlasting impacts on future outcomes in health, education, crime, and labor market (Carneiro and Ginja 2014; Chetty, 2011; Currie, 2001; Heckman et al. 2010; Ludwig and Miller, 2007; Ludwig and Phillips, 2008; Muennig et al. 2011). Accordingly, the findings from this literature indicate that early childhood investments can produce substantial benefits for these individuals and the society at large. Furthermore, the returns to investments are significantly higher the earlier they are made due to complementarities in skill formation and the longer life span over which the benefits can be accrued (BenPorath, 1967; Heckman, 2006; Almond and Currie, 2011ab). Complementing this literature has been a growing number of studies that has demonstrated the importance of environments and conditions that individuals encounter during in utero development. These studies suggest that the risk of poor outcomes in later stages of life in the domains of education, labor market and health may actually originate from exposures to adverse conditions such as air pollution or inadequate nutrition, or risky maternal behaviors such as smoking and alcohol abuse (Almond and Mazumder, 2011; Almond et al., 2014; Cesur et al., in press; Scholder et al., 2014; Hoynes et al., 2015; Schultz-Nielsen et al. 2014; Yeung et al., 2014). One lesson learned from this research is that the importance of prenatal period should not be overlooked when making decisions about policy interventions designed to promote the future well-being of individuals (Almond and Currie, 2011a; Shonkoff and Phillips, 2000). To the extent that human development, skill formation in particular, is a dynamic process, in which early inputs are strongly linked to 
the productivity of later inputs, interventions targeted pregnant women as well as those who are at childbearing age may actually be more optimal than those interventions that come later in life (Almond and Currie, 2011ab).

The literature on the long-term consequences of fetal conditions on the well-being of individuals has been growing since the pioneering work by Stein in the 1970s, which discovered evidence of health impairments for children and adults in relation to exposure to the 1944-45 Dutch "Hunger Winter" in specific periods of gestation (e.g., Stein, et al., 1972; Stein et al., 1975). The most common approach in this literature is the use of extreme and negative events such as famines (e.g., the Dutch Hunger Winter, the Bangladeshi famine of 1974, and the Chinese famine of 1959-61) or disease outbreaks (e.g., the 1918 influenza epidemic) as natural experiments. ${ }^{1}$ While the majority of the previous studies have focused on health outcomes, there has been growing interest in exploring whether the events and the conditions experienced in utero might also extent to outcomes related to human capital development (e.g., Almond, 2006; Almond and Mazumder, 2011; Almond et al., 2014; Field et al., 2009; Majid, 2013; Neelsen and Stratmann, 2011; Scholte et al., 2012; Schultz-Nielsen et al., 2014). ${ }^{2}$ The consensus finding in these studies is that exposure to disease environment or malnutrition during the period of gestational development results in poor human capital outcomes measured by educational attainment, employment, and earnings. ${ }^{3}$

\footnotetext{
${ }^{1}$ See Currie (2009) and Almond and Currie (2011a, b) for reviews of this literature.

${ }^{2}$ See Almond and Currie (2011) for a review of studies focusing on non-health end points including human capital outcomes.

${ }^{3}$ The causal link between malnutrition in utero and academic success can be conceptualized by a human capital model, which describes skill formation as a continuous process that starts with conception (Heckman, 2006). More detailed information on the possible mechanisms for the impact of malnutrition in utero on human capital formation can be found in Almond et al. (2014) and Schultz-Nielsen et al. (2014).
} 
In this paper, we revisit the question as to whether potential malnutrition experienced by individuals during the critical period of fetal development has an impact on their academic proficiency as adolescents. In order to address the confounding factors associated with exposure to malnutrition in utero, we focus on adolescents born in Denmark to immigrant parents from predominantly Muslim countries and then exploit the overlap of their time in utero with the month of Ramadan in a natural experiment research design. The outcomes that we consider are standard test scores drawn from the Danish administrative records on the subjects of Danish, English, Math, and Science. In addition to comparing Muslim children based on their exposure to Ramadan in utero, we also utilize a sample of children born to immigrant parents from predominantly nonMuslim countries as an additional control group. The sample of non-Muslim children allows us to implement a difference-in-differences strategy that would help us eliminate the impact of potential seasonality in the school achievement outcomes.

Our paper provides a fresh contribution to the growing literature on the impact of in utero conditions on later life outcomes of individuals. Our analysis is well-motivated because the balance of the literature is tilted towards studies focusing on malnutrition associated with famines. The investigations focusing on milder forms of malnutrition are relatively less common, despite the fact that the populations affected by less intense malnourishment are much larger (Almond and Currie, 2011a; Schultz-Nielsen et al., 2014). Furthermore, the vast majority of individuals affected by severe malnutrition in utero due to famines live in less developed countries, which usually lack the financial resources, the infrastructure, or the institutional conditions to cope with or reverse the problems faced by affected individuals. Therefore, the findings from these studies cannot 
necessarily serve as a reliable guide to the experiences of individuals living in developed countries. Similarly, conditions, which lead to milder forms of malnutrition, are more amenable to improvements by individual behaviors. Accordingly, there is a wider scope for policy interventions designed to counter the adverse effects of milder malnourishment compared with famines (Almond and Currie, 2011a; Schultz-Nielsen et al., 2014).

Exceptions to the studies of extreme events like famines are a series of recent papers focusing on the overlap between pregnancy and the month of Ramadan, during which many Muslims refrain from eating and drinking during daylight hours. These studies include Almond and Mazumder (2011), Almond et al. (2014), Macid (2013), Schultz-Nielsen et al. (2014), and Van Ewijk (2011). ${ }^{4}$ The approach followed in the present analysis most closely resembles the one adopted by Almond et al. (2014), who use school register data from England to examine the impact of Ramadan exposure in utero on math, reading, and writing assessments of immigrant children with Pakistani and Bangladeshi origin. The authors then estimate difference-in-difference models, in which the school achievements of Muslim children are compared to a control group of Caribbean students based on exposure to Ramadan. Their results indicate that Muslim children who were exposed to Ramadan in utero during the first trimester of pregnancy score significantly lower on all three types of assessments. The other Ramadan papers listed above focus on either employment or health outcomes (Mazumder and Almond, 2011; Schultz-Nielsen et al., 2014; Van Ewijk, 2011) or rely on survey data from Indonesia (Majid, 2013; Van Ewijk, 2011). In fact, with the exceptions of a few recent

\footnotetext{
${ }^{4}$ Almond and Mazumder (2011) use data from multiple sources including vital records and health statistics from Michigan and census data from Iraq and Uganda. Majid (2013) considered several life-cycle outcomes including cognitive test scores and study hours in elementary school in addition to birth weight, child labor, and adult labor market outcomes. However, he uses survey data from Indonesia.
} 
studies (e.g., Almond et al., 2014; Schultz-Nielsen et al., 2014), most of the previous research on the subject relies on survey data, which suffer from both attrition and measurement problems. In contrast, we use data from official administrative records on outcome measures.

We argue that it is important to assess the extent to which findings in Almond et al. (2014) can be generalized to immigrant populations to other developed country settings like Denmark. Furthermore, the Muslim population considered in Almond et al. (2014) includes those with Bangladeshi and Pakistani origin. Since we have register data on the entire Danish population, the Muslim children in our sample come from a much more diverse set of Muslim backgrounds including those from Turkey, Iraq, Pakistan, Afghanistan, Somalia, and Palestine. Accordingly, it is less likely that our findings are driven by the religious, cultural, or traditional practices unique to a particular Muslim group, and therefore more likely to be representative of all Muslims. Finally, Almond et al. (2014) rely on one's birth date and assume a normal gestation length of 266 days when they determine overlap between Ramadan and specific periods of gestation. In contrast, we use data from the Danish birth registry, which includes exact information on gestation length and birth date for everyone in our sample. We can therefore eliminate the possibility of misclassification in the assignment of exposure to Ramadan in utero.

We also go beyond Almond et al. (2014) by exploring the extent to which the impact of fetal exposure to Ramadan on academic success is heterogeneous along various characteristics of Muslim students including gender and socio-economic status. There is evidence to suggest that nutritional insults during the fetal period may leave a permanent memory throughout life, and some of the effects (e.g., insulin secretion and action) may 
be gender-specific (Jones et al., 2006; Sugden and Holnes, 2002). Even if the biological mechanisms affecting fetal development were the same for males and females, there could still be gender-specific differences in parental or societal responses to any health and cognitive problems that children might experience as a result of fetal exposure to malnutrition. If males and females differ in their responses to these measures or to interventions aimed at countering any cognitive or health impairments associated with fetal exposure to Ramadan, then this may explain any gender-specific heterogeneity in the pattern of results.

There is growing evidence in economics suggesting that health shocks and subsequent interventions can have different long-term effects on boys and girls (Almond and Currie, 2011b; Currie and Yelowitz, 2003; Orr, 2003). There could also be biological differences between males and females in adapting to these problems or the types of roles they are assigned to in the society (Yueng, 2014). Accordingly, several studies in health sciences document that fetal under-nutrition has more deleterious effects on the health of females than males (e.g., Chen et al., 2014; Lv et al., 2015). ${ }^{5}$ However, the empirical investigations of the fetal origins hypothesis conducted by economists have not yet considered the possibility that the effects of exposure to intrauterine malnutrition on nonhealth outcomes might differ by gender. As we discuss below, stratifying the sample by gender turns out to be an important consideration. The revealing of any gender specific pattern may have implications for optimal public policy by providing compelling

\footnotetext{
${ }^{5}$ There is also evidence to illustrate that female adult health is more sensitive to childhood conditions than male adult health (Chapman, 2009; Luo and Waite, 2005). The exact mechanisms of the gender differences of fetal under-nutrition on health remain unclear. However, such differences are observed in animal studies as well (e.g., Baker et al., 2015; Zambrano et al., 2005; 2006).
} 
evidence for targeted interventions for populations exposed to malnutrition or other risk factors in utero, especially in more resource-constraint economies.

Similarly, assessing any evidence for heterogeneity with respect to socioeconomic status is important because parental behaviors and family resources may have the potential to mitigate the impact of poor health on academic success. There is a large literature documenting differences by socioeconomic status in both the quality and quantity of time parents spend with school-age children (e.g., Guryan et al., 2008; Kalil et al., 2012). Therefore, it is plausible that high-SES Muslim parents might have the resources necessary to provide support at home and outside the school day to counter the impact of any adverse conditions in utero. If there is indeed considerable heterogeneity in the impact of fetal exposure to Ramadan on school outcomes, then the evidence obtained from an approach that fails to take into account these sub-group dynamics might be incomplete and unreliable.

The rest of the paper is structured as follows. Section II presents the data. Section III describes the empirical strategy. Section IV presents the results and Section V concludes the paper.

\section{Data}

Our data are drawn from Danish administrative registers, maintained by Statistics Denmark. We limited the analysis to children born in Denmark during the period 19851995 for two reasons: First, at the time of our data collection, the Danish administrative registers on education outcomes only included information on completed exams for the 
years 2002-2010. ${ }^{6}$ Second, information on gestational age, birth date, unique personal identifiers of the newborns and their biological parents and their immigration status is included in the birth registry, which only includes children born in Denmark. ${ }^{7}$

We restricted the analysis sample to full term born (born in week 39-42) children with an identified mother. Restricting the sample to only full term born children gives us a more homogenous sample. This is also the approach taken in most of the previous research (e.g., Almond and Mazumder, 2011). Furthermore, people with a shorter gestational age are less likely to overlap with the month of Ramadan in utero. Therefore, by limiting the sample to full term children, the categories of fetal overlap with the month of Ramadan are more comparable to each other. A child is defined as Muslim if both the mother and the child is an immigrant from a country with more than $90 \%$ of Muslims. According to Statistic Denmark, the definition of being an immigrant includes both immigrants and descendants of immigrants. By using this definition we make sure that the father of the child is also from a Muslim (or non-Muslim for the non-Muslim sample) country as well. Following Schultz-Nielsen et al. (2014), a child is defined as NonMuslim if both the mother and the child is an immigrant (same definition as above) from a country with up to $15 \%$ of Muslims.

The educational outcomes we examine include standardized test scores from national compulsory exams held by the end of the 9th grade, when Danish children are around 16 years of age. We consider standardized test scores on four mandatory subjects:

\footnotetext{
${ }^{6}$ Notice that children born in 1985 are all children that started school after the year they turned 6 years, and the children born in 1995 are all children that started school before the year they turned 6 . We have tested if the results differ when leaving children born in the years 1985 and 1995 out of the sample. The results do not change so we have included these observations in the results.

${ }^{7}$ We use the information on gestational age from the birth registry to calculate overlap with Ramadan. An evaluation of the birth registry (Blenstrup and Knudsen, 2011) has concluded that information included in this registry is of high quality with regard to both validity and coverage.
} 
Danish, English, Math, and Science (i.e., Physics and Chemistry). Although these subjects are mandatory for all students, not all students take the exams and the test scores are occasionally missing and consequently the number of observations varies across subjects. ${ }^{8}$ In Table 1 we present the descriptive statistics for test scores among Muslims and Non-Muslims. As the point system changed in Denmark in 2007 we have standardized the test scores to have mean zero and standard deviation unity for each subject in a given year (calculated for all students in Denmark, not only those included in the estimation sample). Accordingly, the negative means among all the Muslim groups reflect that scores among Muslim children are below the average of all the children in Denmark that completed these test scores. In general most of the means of the test scores are also negative among Non-Muslims. However, in all groups (full sample, females, and males) the Non-Muslim children score relatively higher compared to the Muslim children.

For each child in our sample, we construct binary indicators to determine whether the period of the Ramadan overlapped with child's time in utero. We generate an indicator for overlap with Ramadan in each of the trimesters, where the first trimester refers to the months of 1-3 in utero, the second trimester includes the months of 4-6, and the third trimester refers to the months of 7-9 during time in utero. Additionally, we also construct an indicator for "Month 0 ," which represents individuals who were conceived during Ramadan. The omitted category in our analyses includes those who are certainly not exposed to Ramadan in utero.

\footnotetext{
${ }^{8}$ The test score in Danish is constructed as the average of two oral and one written tests. The test score in Math is the average scores between one written test administrated in 2007 and two written tests administered in 2007 and after (in 2007 there were introduced two mandatory written Math exams).
} 
In all of our models we control for a comprehensive list of variables. The following variables are measured at the time of the child's birth: gender (in the full sample), year of birth, month of birth, mother's age (and mother's age squared), years since mother's migration (and years since mother's migration squared), number of siblings, being first born, and mother being married or cohabiting. The following variables are measured when the child was 15: family gross income, mother's employment status and mother's education. To measure mother's education we include 2 indicators. One indicator for when the highest level of education is basic education (maximum 9 years of schooling) and one indicator for when the mother's education is not completed in Denmark. We include this last indicator because information on the level of education is uncertain in the register data, when the education is not completed in Denmark. We also control for a variable measuring the child's age when the child completed the exam (and it's squared). Furthermore, we include mother's country of origin and school fixed effects. Table 2 shows the descriptive statistics for the full sample, boys and girls, for Muslims and Non-Muslims.

\section{Empirical Model}

The estimation of the impact of potential fetal malnutrition on academic proficiency poses two econometric challenges that need to be overcome. First, the fetal exposure to malnutrition is unlikely to be random with respect to school outcomes. Therefore, an approach that fails to account for the endogeneity of fetal exposure to malnutrition would yield biased estimates. We deal with the endogeneity problem by exploiting the coincidence of the month of Ramadan with the period of fetal 
development. To the extent that the timing of pregnancy is unrelated to the occurrence of Ramadan, exposure to Ramadan would represent a natural experiment. ${ }^{9}$ Then one can compare the school outcomes of children who were in utero during the month of Ramadan with those who were not, assuming that some Muslim women might have fasted during Ramadan.

It is important to note that we do not observe the actual fasting status of pregnant Muslim mothers in our data. In other words, our approach amounts to estimating an intent-to-treat effect. ${ }^{10}$ To the extent that at least some pregnant Muslim women fast during Ramadan, our analysis would produce a lower (or conservative) bound for the true effect of fasting on school outcomes. ${ }^{11}$

The second challenge that we must confront is the potential seasonality in the school outcomes. There is substantial evidence to indicate that the month of a child's birth matters for outcomes both at birth and later in life. ${ }^{12}$ Furthermore, these strong

\footnotetext{
${ }^{9}$ Several studies that consider the question of selective timing of pregnancy find no evidence to indicate that maternal characteristics are systematically related to the timing of conception relative to the month of Ramadan (e.g., Almond and Mazumder, 2011; Almond et al., 2014; Schultz-Nielsen et al., 2014). In our sample, we estimated our models using mother's education, family income, and mother's employment status as an outcome variable. This exercise did not show any evidence of selective timing in our sample. ${ }^{10}$ This is actually an advantage of our analytic approach rather than a limitation because it implicitly allows us to avoid the difficulty of addressing the endogeneity of actual fasting. By estimating an intent-to-treat effect, we assume that Muslim women who fast during pregnancy differ from those who do not in unobservable ways.

${ }^{11}$ The rates of fasting vary across countries. For example, estimates obtained from countries such as England, Gambia, Iran, and Singapore, the United States, and Yemen range from 70 to 90 percent. We do not have estimates specific to Muslim women in Denmark. However, anecdotal evidence from Danish hospitals indicates that fasting during pregnancy is not uncommon. Our conversations with Dr. Jacob Alexander Lykke of Copenhagen University Hospital supported this prediction.

${ }^{12}$ For example, Buckles and Hungerman (2013) suggest that the seasonal variation in these outcomes is due to selection, i.e., children born in different seasons are not initially similar but rather are conceived by different groups of women. They show that the systematic fluctuations in maternal characteristics on education, race, age, and marital status exhibit systematic fluctuations during the course of a year are responsible for much of the strong relationship between season of birth and later life outcomes. A recent paper by Currie and Schwandt (2013) show that children conceived in the month of May are more likely to be premature since gestation length for these children coincides with a higher influenza prevalence in January and February, when these babies are nearing full term. They also show an increase birth weight for
} 
seasonal patterns have been documented for both developing and developed countries including countries including Denmark (Olsen, 1989; Torrey et al., 1997; Wohlfahrt, 1998). Normally, the seasonality could simply be controlled for by including month of birth indicators in the empirical models if one has a large number of birth cohorts. ${ }^{13}$ This is because Ramadan is based on the lunar calendar, and thus moves gradually (by exactly 11 days every year) throughout the Gregorian calendar year, completing a full circle in 36 years. In our case however, we only have 11 cohorts of children who were born between 1985 and 1995. The month of Ramadan started on May $21^{\text {st }}$ in 1985 and on February $1^{\text {st }}$ in 1995 . Then, assuming a normal gestation length of 266 , only those children who had been conceived roughly between the dates of May $11^{\text {th }}$ and August $28^{\text {th }}$ could have possibly been exposed to Ramadan during in utero evolution. In other words, almost all of the children in our treatment group must have been conceived during the months of summer. To the extent that children conceived in the summer months are different from those conceived at other times of the year in ways that are correlated with cognitive development, failing to account for such seasonality would cause bias in the estimates.

Our main approach to accounting for the impact of seasonality on academic proficiency is to implement a difference-in-differences strategy, in which we use a sample of students whose parents had migrated to Denmark from non-Muslim countries as an additional control group. The assumption in this approach is that any Ramadan effect on the test scores of non-Muslim students should be due to seasonality since the coincidence of Ramadan with their time in utero should not matter for them. Having said

children conceived in summer months driven by a higher pregnancy weight gain among mothers who conceive during the summer months.

${ }^{13}$ In fact, in a recent analysis of the impact of intrauterine malnutrition on labor market outcomes using administrative data from Denmark, Schultz-Nielsen et al. (2014) was able to account for seasonality by only using month of birth dummies in their models because they had a large number of cohorts. 
that, we will also present estimates from the Muslim only sample, which would account for the seasonality only partially by including birth month dummies.

The empirical model for the difference-in-difference strategy can be expressed as follows:

$$
\begin{aligned}
\mathrm{Y}_{\mathrm{i}}= & \alpha_{0}+\alpha_{1} \text { Muslim }_{\mathrm{i}}+\mathrm{X}_{\mathrm{i}} \alpha_{2}+\mathrm{X}_{\mathrm{i}}^{*} \text { Muslim }_{\mathrm{i}} \alpha_{3}+\mu_{0} \text { Conceived_in_Ramadan }_{\mathrm{i}}+ \\
& \sum_{j=1}^{3} \mu_{\mathrm{j}} \text { Trimester }_{\mathrm{ij}}+\beta_{0} \text { Conceived_in_Ramadan }_{\mathrm{i}}{ }^{*} \text { Muslim }_{\mathrm{i}}+\sum_{j=1}^{3} \beta_{\mathrm{j}} \text { Trimester }_{\mathrm{ij}}{ }^{*} \\
& \text { Muslim }_{\mathrm{i}}+\text { Country }_{\mathrm{i}}+\text { School }_{\mathrm{i}}+\varepsilon_{\mathrm{i}}
\end{aligned}
$$

where Y represents one of the outcome measures for child i. The four treatment variables are "Conceived_in_Ramadan ${ }_{\mathrm{i}}$ " which is a binary indicator for whether child i was conceived during the month of Ramadan; "Trimester ${ }_{\mathrm{i} 1}$, Trimester $_{\mathrm{i} 2}$ and Trimester $_{\mathrm{i} 3}$ " are binary indicators for whether the beginning of Ramadan coincided with the $1^{\text {st }}, 2^{\text {nd }}$, and $3^{\text {rd }}$ trimester of pregnancy of the mother of child i, respectively. The omitted category includes those who were "certainly not exposed to Ramadan." In equation (1), we also control for binary indicators for year and month of birth, mother's age and age-squared, mother's number of years since migration and its squared, number of siblings, a binary indicator for being the first child, binary indicator for the mother's marriage status, mother's education, mother's employment status at age 15 , gross family income, child's age at exam. All of these variables are interacted with the Muslim indicator. Finally, we also control for country of origin to account for country-specific differences in cultural and religious practices and school fixed effects to account for neighborhood differences that might be correlated with the socio-economic, cultural, and religious characteristics of 
immigrants. Therefore, the identification in equation (1) comes from within school differences among children with the same country of origin in their exposure to the month of Ramadan. In equation (1), the difference-in-difference estimates are $\beta_{0}-\beta_{3}$. which represent the impact on the test scores of those Muslims who were exposed to Ramadan during a particular trimester in utero compared to Muslims with no fetal exposure to Ramadan, relative to any effect that might exist for non-Muslim children due to seasonality.

\section{Results}

We begin our discussion of the results by presenting the estimates from a specification that focuses on the Muslim sample of students only. ${ }^{14}$ Note that in this specification, the identification is based on only the impact of fetal exposure to Ramadan relative to other Muslim students who were not in utero during Ramadan. Therefore, the impact of seasonality is captured only partially in these models. Table 3 presents the estimates on Ramadan exposure indicators for each of the four outcomes separately for the full sample as well as for females and males.

Focusing on the estimates for the full sample shown in column (1), all of the estimates are small in magnitude and none of them are estimated with much precision. One explanation for these null effects could be that being in utero during the month of Ramadan might indeed be inconsequential for the school outcomes of Muslim immigrants. An alternative explanation could be that the impact of exposure might be heterogeneous along various characteristics of Muslim children such as gender and socio-

\footnotetext{
${ }^{14}$ In the interest of space, we only present estimates on the four binary treatment indicators representing fetal exposure to Ramadan at different stages of pregnancy. However, the full results are available from the authors upon request.
} 
economic status. Then an analysis focusing on the full sample may mask some of this heterogeneity and in some cases yield null effects, especially in cases in which the subgroup effects are opposing to each other.

Turning to gender specific estimates presented in columns (2) and (3), we find that there may indeed be significant gender differences in the way fetal exposure to Ramadan affects test scores of Muslim students. The estimates on the test scores for the female sample are negative in 10 of the 12 trimester coefficients and statistically significant for the first and second trimester exposure indicators for the English assessment. More specifically, the English test scores of female Muslim students who were exposed to the start of Ramadan in the first trimester of pregnancy are 0.19 standard deviations less than those who were certainly not in utero during Ramadan. Similarly, those with second trimester in utero exposure to Ramadan score about 0.20 standard deviations worse than those who had no fetal exposure to Ramadan.

Turning to males in column (3), the overall evidence from the set of estimates across four outcome models is much more blurry, with no particular pattern emerging in terms of the direction of the effects. Surprisingly however, the only two estimates that are statistically significant at conventional levels have a positive sign, suggesting that first trimester in utero exposure to Ramadan is associated with an increase in the test scores for Danish and Math assessments. There may be several explanations for these counterintuitive results. ${ }^{15}$ First, it may be due to fact that seasonality is not properly

\footnotetext{
${ }^{15}$ We also estimate similar models using the non-Muslim sample only. As shown in Appendix Table 1, these estimates are overwhelmingly indistinguishable from zero. In particular, none of the estimates for the full sample and the sub-sample for girls is statistically significant. Among boys, all of the estimates are insignificant with the exception of one positively signed estimate for the outcome of Science assessment, which is barely significant at the 10 percent level. The most likely explanation for this counterintuitive result, aside from data anomaly, is potential seasonality, especially since the same estimate is also positive but not significant for Muslims boys.
} 
captured in these models given that we only have 11 years of data. Second, the results may reflect positive selection among boys due to gender-specific biological differences. If, for example, males are in general more fragile and vulnerable to fetal insults than girls, then a given health shock, such as fetal exposure to malnutrition, may cull boys while girls may survive (e.g., see Almond and Mazumder, 2008; Almond and Currie 2011b; Kraemer, 2000). In this case, the average health of the surviving males exposed to fetal malnutrition during Ramadan may actually be better than those of female survivors. Third, gender differences in the effects could result from parental investments or societal responses to health shocks reflected by differences in preferences between boys and girls (Almond and Currie, 2011b, Lhila and Simon, 2008). However, this is more likely to serve as an explanation for a null effect than a positive effect for boys.

The estimates from the difference-in-differences model specified in equation (2) are presented in Table 4. For each outcome measure, we present estimates for a binary indicator representing conception during Ramadan and three dummy variables representing exposure to Ramadan in one of the three trimesters of pregnancy. The first column shows the estimates for the full sample and then the estimates for females and males are presented in columns (2) and (3). In addition to month of birth fixed effects, these models further control for seasonality by comparing Muslim and non-Muslim students under the assumption that any seasonal patterns should affect both groups similarly.

As shown in column (1) of Table 4, none of the estimators is statistically significant for any of our outcome measures for the full sample. This is consistent with the pattern obtained in Table 3, in which we also had no detectable pattern for the full 
sample. Turning to the estimates for females shown in column (2), we see that the second trimester effect obtained for the English test score in Table 3 persists in the difference-indifferences model. Specifically, the second trimester in utero exposure to Ramadan is associated with a 0.39 standard deviation reduction in the English test scores among Muslim female students. Furthermore, we also obtain a negative first trimester effect for the Danish exam score among Muslim girls as well. The estimates for males shown in column (3) are again much smaller in magnitude and also estimated without precision for all indicators, except for the Science score among those who were exposed to Ramadan in utero during the third trimester.

Finally, we present estimates from the analysis conducted separately by socioeconomic status (SES). Our definition of low-SES is based on maternal education and employment status. In particular, we classify a student as coming from a low-SES background if her mother had no work and had less than nine years of schooling when the student was 15 years of age. Based on this definition, we have 3,578 and 320 observations classified as low-SES among Muslims and non-Muslims, respectively. Note that creating a definition for high-SES is complicated in our sample because the sample sizes are significantly reduced if we focus on mothers who are employed and have more than nine years of formal schooling when the student was 15 years of age. Therefore, we present estimates for the non-Low-SES sample (i.e., those who are not in the low-SES group) in Appendix Table 2. ${ }^{16}$

\footnotetext{
${ }^{16}$ Note that we also tried to create high-SES samples based only employment or only on education. However, it is hard to imagine that such measures capture SES properly since SES is essentially a multidimensional and aggregate measure reflective of an individual's position in the society along the dimensions of education, occupation, income, social standing in the community. Nevertheless, results based on these samples are similar in essence to those in Appendix Table 2 and are available from the authors upon request. In overwhelming majority of the cases, the estimates presented in Appendix Table 2 are statistically insignificant. Focusing on the estimates for females and males illustrated in columns (2) and
} 
The low-SES estimates shown in Table 5 are dramatically different from those that are presented earlier. To begin with, the estimates from the full sample of low-SES children are all negative in sign and statistically significant in all cases with the exception of two estimates out of sixteen. ${ }^{17}$ Furthermore, the estimates are all large ranging from 0.40 standard deviation to over 0.90 standard deviation. The general picture in column (1) is one that indicates that fetal exposure to Ramadan has large and negative effects on all of the four assessment scores regardless of the timing of exposure.

When we turn our attention to gender-specific estimates presented in columns (2) and (3), it is revealed that the effects for Danish and English are overwhelmingly concentrated on low-SES female Muslim students, with no precisely estimated effects among males with the exception of Math. The effects are large and precisely estimated for the first trimester exposure for Danish and the first and the third trimester exposures for English. The estimates for males are only statistically significant for Math for those exposed in the second and third trimester.

Combined with the estimates in Appendix Table 2, the results from the analyses based on SES suggest that potential fetal malnutrition captured by Ramadan exposure in utero not only has harmful effects on the academic proficiency of Muslim children, but it

\footnotetext{
(3), the only exceptions to statistical insignificance are one estimate for the third trimester exposure to Ramadan for females for the Math assessment and two estimates for the third trimester exposure for the assessments of English and Science.

${ }^{17}$ Unlike the results in the previous tables, we also obtain negative and significant estimates for the indicator representing an overlap between Ramadan and the time of conception. One possible explanation for the negative estimates for those exposed to Ramadan in the month of conception may be selection that is attributable to certain behavioral differences among the Muslim individuals during the month of Ramadan. For example, it is permissible for couples to engage in sexual intercourse during Ramadan as long as it takes place outside fasting hours, many Muslims who are unsure may abstain from sexual activity altogether during Ramadan. Similarly, many Muslims including the moderate ones refrain from smoking and consuming alcohol during the month of Ramadan regardless of whether they fast or not. These different behavioral practices may then be correlated with other unobservable characteristics of the parents that are related to the cognitive outcomes of their children. Therefore, being conceived in the month of Ramadan may simply reflect selection rather than having a causal interpretation.
} 
may also exacerbate the disparities in cognitive development between children from a low-SES background and the rest of the population.

\section{Conclusion}

The goal of this paper is to provide causal evidence on the impact of fetal exposure to malnutrition on the academic proficiency of Muslim students. To accomplish this goal, we use administrative data from Denmark on students born in Denmark to immigrant mothers from predominantly Muslim and predominantly non-Muslim countries using a difference-in-differences empirical framework. Our outcome measures are the standardized national test scores on the subjects of Danish, English, Math, and Science completed by the end of the $9^{\text {th }}$ school year. Our results indicate that fetal exposure to Ramadan causes a negative impact on the achievement scores of Muslim students, especially females. Our analysis further reveals that most of these effects are concentrated on the low-SES children. One implication of this finding is that fetal insults such as exposure to malnutrition may not only hamper the cognitive development of children subject to such insults in the long-term, but it may also complicate the efforts of policy-makers in improving the human capital, health, and labor market outcomes lowSES individuals.

While the results obtained in this paper clearly have implications for Muslim populations around the world, our findings are relevant for much wider populations including those in Western societies, where millions of pregnant women continue to receive inadequate care and nutrients during pregnancy. However, the relative public dollars allocated for interventions designed to help economically disadvantaged pregnant 
women are only a very small fraction of total public funds used for social safety net. For example, the Special Supplemental Nutrition Program for Women, Infants, and Children (WIC) is a federal program in the United States that provides grants to States for supplemental foods, health care referrals, and nutrition education for low-income pregnant, breastfeeding, and non-breastfeeding postpartum women, and to infants and children up to age five who are found to be at nutritional risk. However, the WIC is one of the smallest federal programs in terms of the dollars spent and the size of the population it serves. ${ }^{18}$ Our findings indicate that interventions like WIC that are aimed at improving the conditions of low-income pregnant women and newborn babies might have long-term positive effects for the cognitive development of children.

\footnotetext{
${ }^{18}$ For example, the spending by the federal government on WIC was six billion dollars in 2014 compared to $\$ 49$ billion spent on housing subsidies or $\$ 302$ billion for Medicaid, a healthcare program for lowincome individuals and families in the United States (see http://federalsafetynet.com/welfare-budget.html)
} 


\section{References}

Almond, D., \& Currie, J. (2011a). "Killing me softly: The fetal origins hypothesis. The journal of economic perspectives: A journal of the American Economic Association," 25(3), 153.

Almond, D., \& Currie, J. (2011b) "Human Capital Development before Age Five," Handbook of Labor Economics, David Card and Orley Ashenfelter (eds.).

Almond, D., \& Mazumder, B. (2011). "Health capital and the prenatal environment: the effect of Ramadan observance during pregnancy." American Economic Journal: Applied Economics, 56-85.

Almond, D., Mazumder, B. and van Ewijk, R. (2014). “In Utero Ramadan Exposure and Children's Academic Performance.” The Economic Journal. doi: 10.1111/ecoj.12168.

Ben-Porath, Yoram. (1967). "The Production of Human Capital and the Life Cycle of Earnings." Journal of Political Economy, 75(4): 352-365.

Blenstrup, L.T, and Knudsen, L.B. (2011) "Danish Registers on Aspects of Reproduction,” Scandinavian Journal of Public Health, 39 (Suppl. 7), 79-82.

Buckles, K. S., \& Hungerman, D. M. (2013). "Season of birth and later outcomes: Old questions, new answers. "Review of Economics and Statistics, 95(3), 711-724

Carneiro, Pedro and Rita Ginja. (2014). "Long-Term Impacts of Compensatory Preschool on Health and Behavior: Evidence from Head Start." American Economic Journal: Economic Policy, 6(4): 135-173.

Cesur, Resul, Erdal Tekin, and Aydogan Ulker. (In press) "Air pollution and infant mortality: evidence from the expansion of natural gas infrastructure." The Economic Journal.

Chapman, B.P. (2009). "Can the influence of childhood SES on Men and Women's adult Body Mass be explained by adult SES or personality?" Findings from a national sample. Health Psychology 28(4):419-427.

Chen, H., Nembhard, W. N., \& Stockwell, H. G. (2014). "Sex-Specific effects of fetal exposure to the 1959-1961 Chinese famine on risk of adult hypertension." Maternal and child health journal, 18(3), 527-533.

Chetty, Raj \& John N. Friedman \& Nathaniel Hilger \& Emmanuel Saez \& Diane Whitmore Schanzenbach \& Danny Yagan. (2011). "How Does Your Kindergarten Classroom Affect Your Earnings? Evidence from Project Star," Quarterly Journal of Economics, vol. 126(4), pages 1593-1660. 
Currie, Janet. (2001). "Early Childhood Education Programs." Journal of Economic Perspectives, 15(2): 213-238.

Currie, J. and Yelowitz, A. (2000). “Are public housing projects good for kids?" Journal of Public Economics, 75(1): 99-124.

Currie, J., \& Schwandt, H. (2013). "Within-mother analysis of seasonal patterns in health at birth." Proceedings of the National Academy of Sciences, 110(30), 12265-12270.

Field, Erica; Robles, Omar; Torero, Maximo. (2009). "Iodine deficiency and schooling attainment in Tanzania." American Economic Journal: Applied Economics. October, 1(4):140-169.

Guryan, J., Hurst, E., \& Kearney, M. (2008). "Parental education and parental time with children." The Journal of Economic Perspectives, 22, 23-46.

Heckman, J. J. (2006). "Skill formation and the economics of investing in disadvantaged children." Science, 312(5782), 1900-1902.

Heckman, James J., Seong Hyeok Moon, Rodrigo Pinto, Peter A. Savelyev, and Adam Yavitz. (2010). "Reanalysis of the High/Scope Perry Preschool Program." Quantitative economics, 1(1), 1-46.

Hoynes, Hilary, Doug Miller, and David Simon. (2015). "Income, the Earned Income Tax Credit, and Infant Health." American Economic Journal: Economic Policy, 7(1): 172-211.

Jones, A., K.M. Godfrey, P. Wood, C. Osmond, P. Goulden, D.I. Phillips (2006). "Fetal growth and the adrenocortical response to psychological stress, "J Clin Endocrinol Metab, Vol. 91, 2006, 1868-1871.

Kalil, A., Ryan, R., and Corey, M. (2012). "Diverging destinies: Maternal education and the developmental gradient in time with children." Demography, 49, 1361-83.

Kraemer, S. (2000) “The fragile male.” BMJ, 321(7276): 1609-1612, 2000.

Lhila, A., and Simon, K.I. (2008). "Prenatal health investment decisions: Does the child's sex matter?" Demography, 45(4): 885-905.

Ludwig, Jens and Douglas L. Miller. (2007). "Does Head Start Improve Children's Life Chances? Evidence from a Regression Discontinuity Design." Quarterly Journal of Economics, 122(1): 159-208.

Ludwig, Jens and Deborah A. Phillips. (2008). "Long-term Effects of Head Start on Low-income Children." Annals of the New York Academy of Sciences, 1136(1): 257-268. 
Luo, Y. and Waite, L.J. (2005). "The impact of childhood and adult SES on physical, mental and cognitive well-being in later life." Journal of Gerontology B 60(2):S93-S101.

Lv, J., Chen, W., Sun, D., Li, S., Millwood, I. Y., Smith, M. \& China Kadoorie Biobank collaborative group. (2015). "Gender-Specific Association between Tobacco Smoking and Central Obesity among 0.5 Million Chinese People." The China Kadoorie Biobank Study.

Majid, Muhammad Farhan. (2013). "The Persistent Effects of in Utero Nutrition Shocks Over the Life Cycle: Evidence From Ramadan Fasting." Unpublished manuscript.

Muennig, P., Robertson, D., Johnson, G., Campbell, F., Pungello, E. P., \& Neidell, M. (2011). The effect of an early education program on adult health: the Carolina Abecedarian Project randomized controlled trial. American Journal of Public Health, 101(3), 512.

Neelsen, S., \& Stratmann, T. (2011). "Effects of prenatal and early life malnutrition: Evidence from the Greek famine." Journal of Health Economics, 30(3), 479-488.

Olsen J, Frische G, Poulsen AO, Kirchheiner H (1989). "Changing smoking, drinking, and eating behaviour among pregnant women in Denmark." Evaluation of a health campaign in a local region. Scand J Soc Med 17(4):277-280.

Orr, Larry, Judith D. Feins, Robin Jacob, Erik Beecroft, Lisa Sanbonmatsu, Lawrence F. Katz, Jeffrey B. Liebman, and Jeffrey R. Kling. (2003). "Moving to opportunity: Interim impacts evaluation." Final report, U.S. Department of Housing and Urban Development, Office of Policy Development and Research, June.

Shonkoff, J.P., D. Phillips. (2000). "From Neurons to Neighborhoods: The Science of Early Child Development." National Academies Press, Washington, DC.

Schultz-Nielsen, M. L., Tekin, E., \& Greve, J. (2014). "Labor Market Effects of Intrauterine Exposure to Nutritional Deficiency: Evidence from Administrative Data on Muslim Immigrants in Denmark." (No. w20723). National Bureau of Economic Research.

Scholder, Stephanie Hinke Kessler \& George L. Wehby \& Sarah Lewis \& Luisa Zuccolo, (2014). "Alcohol Exposure In Utero and Child Academic Achievement," The Economic Journal, vol. 0(576), pages 634-667, 05.

Stein Z, Susser M, Saenger G, Marolla F. (1972). "Nutrition and mental performance." Science 178:708-13.

Stein ZA, Susser M, Saenger G, Marolla F. (1975). "Famine and Human Development: The Dutch Hunger Winter of 1944-1945.” New York: Oxford University Press. 
Sugden, M. C. \& Holness, M. J. (2002). "Gender-specific programming of insulin secretion and action." J. Endocrinol. 175: 757-767.

Torrey EF, Miller J, Rawlings R, Yolken RH (1997). "Seasonality of births in schizophrenia and bipolar disorder: A review of the literature." Schizophr Res 28(1):138 .

Van Ewijk, R. (2011). "Long-term health effects on the next generation of Ramadan fasting during pregnancy." Journal of health economics, 30(6), 1246-1260

Wohlfahrt, J., Melbye, M., Christens, P., Andersen, A. M. N., \& Hjalgrim, H. (1998). Secular and seasonal variation of length and weight at birth. The Lancet, 352(9145), 1990.

Yeung, G. Y., Van den Berg, G. J., Lindeboom, M., \& Portrait, F. R. (2014). “The impact of early-life economic conditions on cause-specific mortality during adulthood." Journal of Population Economics, 27(3), 895-919.

Zambrano, E., Martinez-Samayoa, P. M., Bautista, C. J., et al. (2005). "Sex differences in transgenerational alterations of growth and metabolism in progeny (F2) of female offspring (F1) of rats fed a low protein diet during pregnancy and lactation." Journal of Physiology, 566, 225-236.

Zambrano, E., Bautista, C. J., Deas, M., et al. (2006). "A low maternal protein diet during pregnancy and lactation has sex- and window of exposure-specific effects on offspring growth and food intake, glucose metabolism and serum leptin in the rat." Journal of Physiology, 571, 221-230. 
Table 1: Descriptive Statistics for Test Scores among Muslims and Non-Muslims

\begin{tabular}{|c|c|c|c|c|}
\hline \multirow{2}{*}{ Panel A: Full Sample } & \multicolumn{2}{|c|}{ Muslims } & \multicolumn{2}{|c|}{ Non-Muslims } \\
\hline & & & & \\
\hline Danish (Oral and Written) & $\mathrm{N}=9,270$ & $\begin{array}{l}-0.538 \\
(0.787)\end{array}$ & $\mathrm{N}=2,021$ & $\begin{array}{l}-0.026 \\
(0.793)\end{array}$ \\
\hline Math & $\mathrm{N}=9,109$ & $\begin{array}{l}-0.704 \\
(0.967)\end{array}$ & $\mathrm{N}=1,999$ & $\begin{array}{c}0.041 \\
(0.957)\end{array}$ \\
\hline English & $\mathrm{N}=8,361$ & $\begin{array}{l}-0.503 \\
(1.150)\end{array}$ & $\mathrm{N}=1,990$ & $\begin{array}{c}0.189 \\
(0.979)\end{array}$ \\
\hline Science & $\mathrm{N}=8,366$ & $\begin{array}{l}-0.464 \\
(1.012)\end{array}$ & $\mathrm{N}=1,938$ & $\begin{array}{c}0.002 \\
(1.004)\end{array}$ \\
\hline Panel B: Females & & & & slims \\
\hline Danish (Oral and Written) & $\mathrm{N}=4,797$ & $\begin{array}{l}-0.401 \\
(0.792)\end{array}$ & $\mathrm{N}=1,038$ & $\begin{array}{c}0.146 \\
(0.791)\end{array}$ \\
\hline Math & $\mathrm{N}=4,712$ & $\begin{array}{l}-0.774 \\
(0.951)\end{array}$ & $\mathrm{N}=1,027$ & $\begin{array}{l}-0.019 \\
(0.973)\end{array}$ \\
\hline English & $\mathrm{N}=4,373$ & $\begin{array}{l}-0.446 \\
(1.192)\end{array}$ & $\mathrm{N}=1,025$ & $\begin{array}{c}0.274 \\
(1.001)\end{array}$ \\
\hline Science & $\mathrm{N}=4,404$ & $\begin{array}{l}-0.420 \\
(1.009) \\
\end{array}$ & $\mathrm{N}=1,004$ & $\begin{array}{c}0.006 \\
(0.990) \\
\end{array}$ \\
\hline Panel C: Males & & & & slims \\
\hline Danish (Oral and Written) & $\mathrm{N}=4,473$ & $\begin{array}{l}-0.685 \\
(0.755)\end{array}$ & $\mathrm{N}=983$ & $\begin{array}{l}-0.207 \\
(0.755)\end{array}$ \\
\hline Math & $\mathrm{N}=4,396$ & $\begin{array}{l}-0.630 \\
(0.980)\end{array}$ & $\mathrm{N}=972$ & $\begin{array}{c}0.105 \\
(0.935)\end{array}$ \\
\hline English & $\mathrm{N}=3,988$ & $\begin{array}{l}-0.565 \\
(1.099)\end{array}$ & $\mathrm{N}=965$ & $\begin{array}{c}0.097 \\
(0.948)\end{array}$ \\
\hline Science & $\mathrm{N}=3,962$ & $\begin{array}{l}-0.513 \\
(1.015) \\
\end{array}$ & $\mathrm{N}=934$ & $\begin{array}{l}-0.003 \\
(1.020) \\
\end{array}$ \\
\hline
\end{tabular}

Notes: Standard deviations are in parentheses. 
Table 2: Descriptive Statistics for Ramadan Exposure Indicators and Control Variables

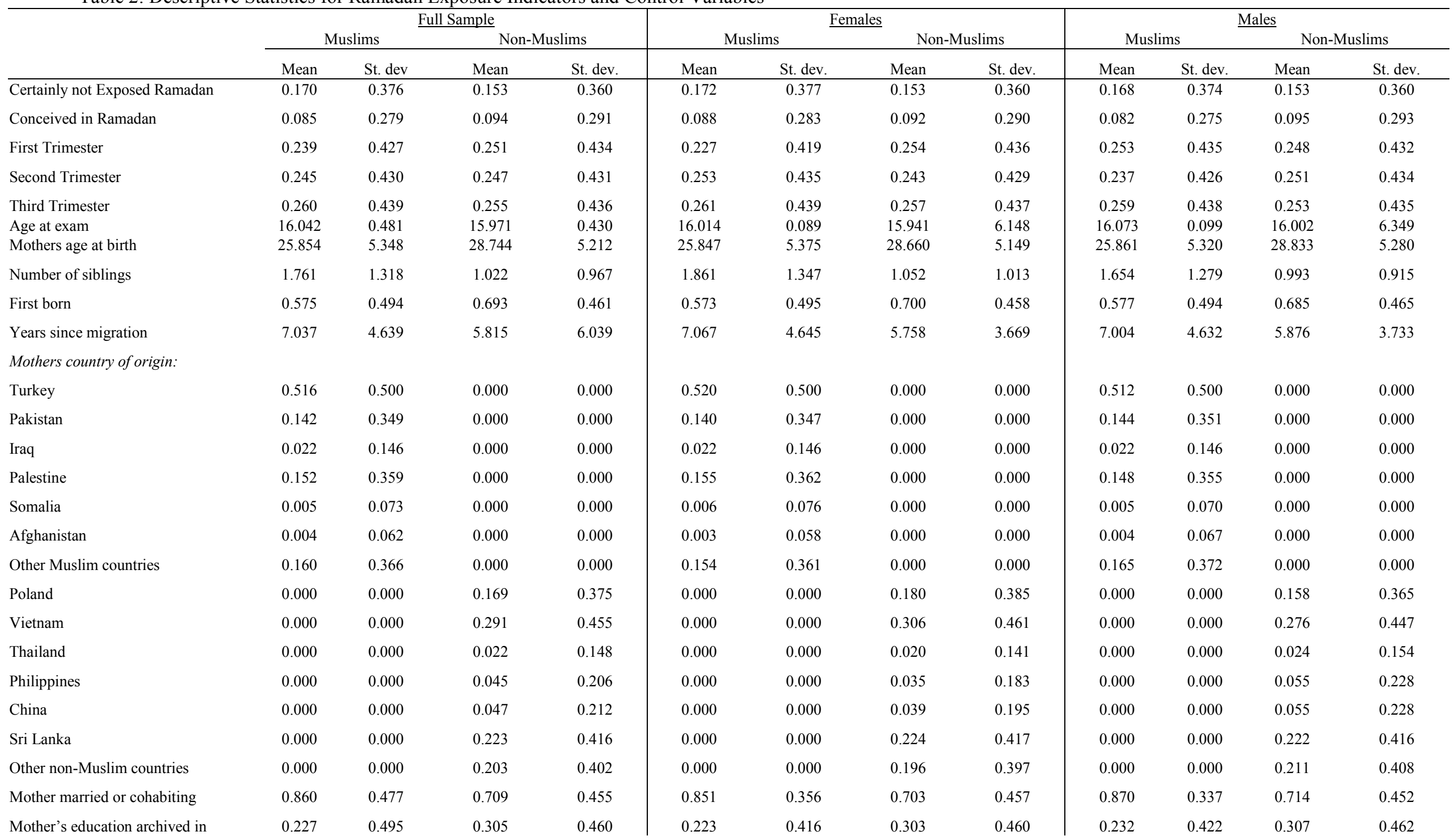




\begin{tabular}{|c|c|c|c|c|c|c|c|c|c|c|c|c|}
\hline \multicolumn{13}{|l|}{ Denmark } \\
\hline Mother has $<9$ yrs of education & 0.650 & 0.419 & 0.413 & 0.493 & 0.655 & 0.475 & 0.376 & 0.485 & 0.644 & 0.479 & 0.453 & 0.498 \\
\hline Mother, employed & 0.429 & 0.495 & 0.697 & 0.460 & 0.421 & 0.494 & 0.710 & 0.454 & 0.439 & 0.496 & 0.683 & 0.466 \\
\hline Log Family income & 3.558 & 0.507 & 3.796 & 0.600 & 3.548 & 0.499 & 3.792 & 0.668 & 3.568 & 0.516 & 3.799 & 0.519 \\
\hline 1985 & 0.009 & 0.094 & 0.003 & 0.054 & 0.008 & 0.089 & 0.004 & 0.062 & 0.010 & 0.099 & 0.002 & 0.045 \\
\hline 1986 & 0.051 & 0.220 & 0.045 & 0.206 & 0.048 & 0.215 & 0.047 & 0.212 & 0.054 & 0.225 & 0.042 & 0.200 \\
\hline 1987 & 0.076 & 0.265 & 0.063 & 0.243 & 0.079 & 0.270 & 0.065 & 0.246 & 0.072 & 0.259 & 0.061 & 0.240 \\
\hline 1988 & 0.087 & 0.282 & 0.088 & 0.283 & 0.086 & 0.280 & 0.084 & 0.277 & 0.089 & 0.284 & 0.093 & 0.290 \\
\hline 1989 & 0.104 & 0.305 & 0.111 & 0.314 & 0.107 & 0.310 & 0.103 & 0.304 & 0.100 & 0.300 & 0.119 & 0.324 \\
\hline 1990 & 0.105 & 0.306 & 0.107 & 0.310 & 0.106 & 0.307 & 0.110 & 0.313 & 0.104 & 0.305 & 0.105 & 0.306 \\
\hline 1991 & 0.128 & 0.334 & 0.124 & 0.329 & 0.123 & 0.329 & 0.116 & 0.320 & 0.132 & 0.339 & 0.132 & 0.339 \\
\hline 1992 & 0.142 & 0.349 & 0.125 & 0.331 & 0.138 & 0.345 & 0.118 & 0.322 & 0.146 & 0.353 & 0.133 & 0.340 \\
\hline 1993 & 0.155 & 0.362 & 0.168 & 0.374 & 0.156 & 0.363 & 0.177 & 0.382 & 0.154 & 0.361 & 0.158 & 0.365 \\
\hline 1994 & 0.137 & 0.344 & 0.160 & 0.367 & 0.139 & 0.346 & 0.171 & 0.377 & 0.134 & 0.341 & 0.149 & 0.356 \\
\hline 1995 & 0.007 & 0.086 & 0.006 & 0.080 & 0.009 & 0.092 & 0.006 & 0.076 & 0.006 & 0.079 & 0.007 & 0.084 \\
\hline \multicolumn{13}{|l|}{ Indicator for month of birth } \\
\hline January & 0.091 & 0.287 & 0.080 & 0.271 & 0.089 & 0.280 & 0.072 & 0.259 & 0.093 & 0.271 & 0.087 & 0.283 \\
\hline February & 0.083 & 0.276 & 0.073 & 0.260 & 0.086 & 0.293 & 0.074 & 0.262 & 0.080 & 0.275 & 0.071 & 0.257 \\
\hline March & 0.089 & 0.284 & 0.089 & 0.284 & 0.095 & 0.280 & 0.090 & 0.286 & 0.082 & 0.288 & 0.087 & 0.283 \\
\hline April & 0.088 & 0.284 & 0.076 & 0.265 & 0.085 & 0.287 & 0.080 & 0.271 & 0.091 & 0.279 & 0.072 & 0.259 \\
\hline May & 0.088 & 0.283 & 0.092 & 0.289 & 0.091 & 0.288 & 0.097 & 0.297 & 0.085 & 0.278 & 0.086 & 0.281 \\
\hline June & 0.088 & 0.283 & 0.087 & 0.282 & 0.091 & 0.284 & 0.078 & 0.268 & 0.084 & 0.279 & 0.097 & 0.296 \\
\hline July & 0.087 & 0.281 & 0.082 & 0.274 & 0.088 & 0.267 & 0.088 & 0.283 & 0.085 & 0.278 & 0.075 & 0.264 \\
\hline August & 0.081 & 0.273 & 0.090 & 0.286 & 0.078 & 0.267 & 0.083 & 0.276 & 0.084 & 0.268 & 0.098 & 0.297 \\
\hline September & 0.078 & 0.267 & 0.084 & 0.278 & 0.078 & 0.255 & 0.075 & 0.264 & 0.078 & 0.270 & 0.094 & 0.291 \\
\hline October & 0.075 & 0.263 & 0.066 & 0.248 & 0.070 & 0.266 & 0.072 & 0.259 & 0.079 & 0.273 & 0.059 & 0.236 \\
\hline November & 0.079 & 0.269 & 0.095 & 0.293 & 0.077 & 0.261 & 0.103 & 0.304 & 0.081 & 0.268 & 0.085 & 0.280 \\
\hline
\end{tabular}


Table 3: Effects of Fetal Exposure to Ramadan on Test Scores of Muslim Students (Muslim Sample Only)

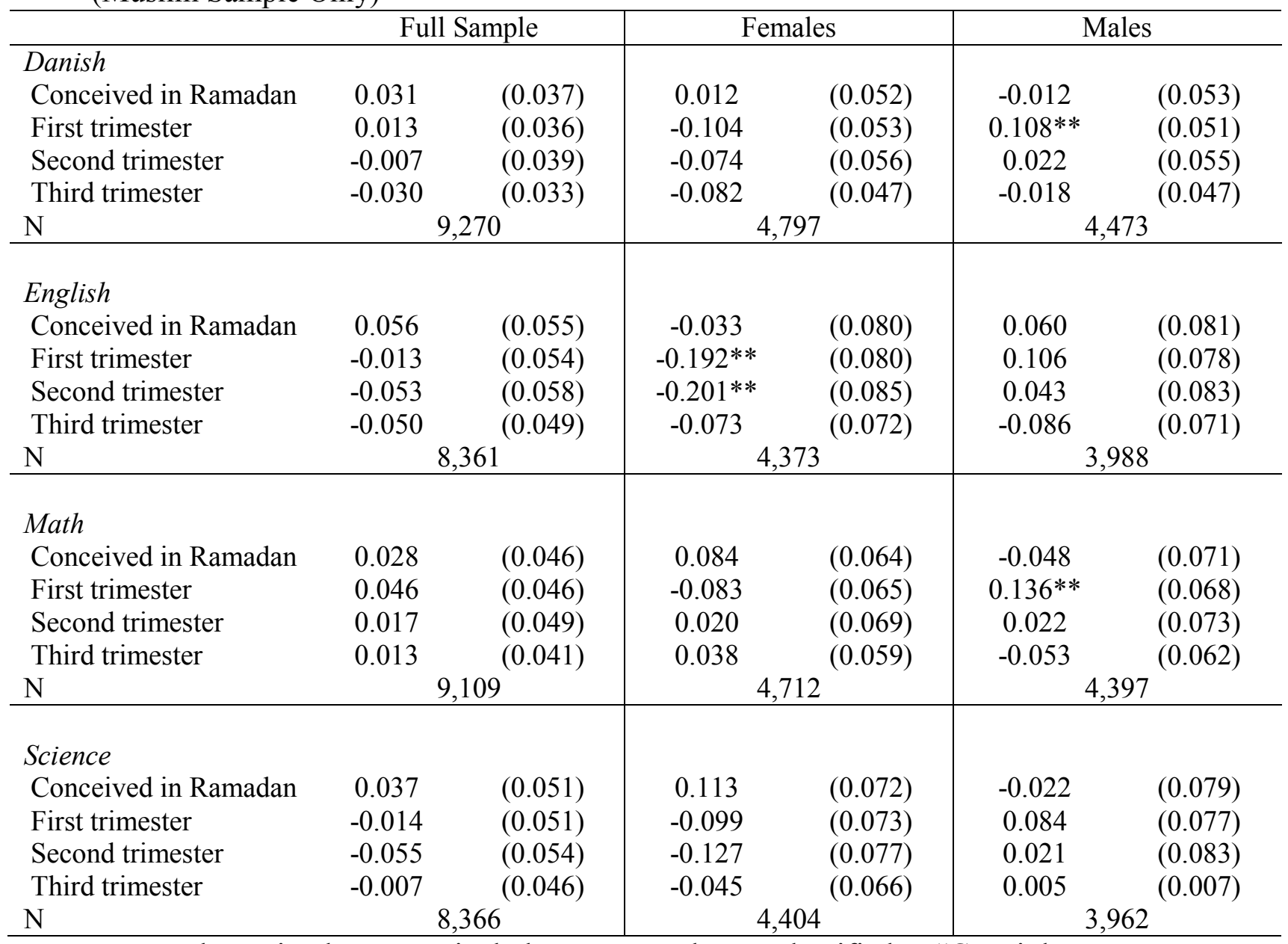

Notes: The omitted category includes persons who are classified as "Certainly not exposed to Ramadan in utero" The following control variables are included in the estimations but not shown: gender (in the sample incl. boys and girls), year of birth, month of birth, mother's age, mother's age squared, years since mother's migration, years since mother's migration squared, number of siblings, first born, mother married or cohabiting, mother's education $<9$ years of schooling, mothers education is not completed in Denmark, mother's employment status at age 15, log of gross family income, child's age at exam. Furthermore, we include mother's country of origin and school fixed effects. $* * *$, and $* * *$ indicate statistical significance at $10 \%, 5 \%$, and $1 \%$ levels, respectively. 
Table 4: Difference-in-Differences Estimate of the Effect of Fetal Exposure to Ramadan on Test Scores of Muslim Students

\begin{tabular}{|c|c|c|c|c|c|c|}
\hline & \multicolumn{2}{|c|}{ Full Sample } & \multicolumn{2}{|c|}{ Females } & \multicolumn{2}{|c|}{ Males } \\
\hline \multicolumn{7}{|l|}{ Danish } \\
\hline Conceived in Ramadan & -0.008 & $(0.090)$ & -0.073 & $(0.138)$ & 0.109 & $(0.133)$ \\
\hline First trimester & -0.063 & $(0.090)$ & $-0.255^{*}$ & $(0.140)$ & 0.151 & $(0.134)$ \\
\hline Second trimester & -0.076 & $(0.095)$ & -0.187 & $(0.143)$ & 0.088 & $(0.141)$ \\
\hline Third trimester & -0.035 & $(0.081)$ & -0.072 & $(0.124)$ & 0.033 & $(0.117)$ \\
\hline $\mathrm{N}$ & \multicolumn{2}{|c|}{11,291} & \multicolumn{2}{|c|}{5,835} & \multicolumn{2}{|c|}{5,456} \\
\hline \multicolumn{7}{|l|}{ English } \\
\hline Conceived in Ramadan & -0.021 & $(0.129)$ & -0.121 & $(0.198)$ & 0.101 & $(0.189)$ \\
\hline First trimester & -0.045 & $(0.129)$ & -0.218 & $(0.202)$ & 0.005 & $(0.190)$ \\
\hline Second trimester & -0.036 & $(0.135)$ & $-0.391 *$ & $(0.207)$ & 0.227 & $(0.202)$ \\
\hline Third trimester & 0.021 & $(0.115)$ & -0.242 & $(0.178)$ & 0.214 & $(0.167)$ \\
\hline $\mathrm{N}$ & \multicolumn{2}{|c|}{10,351} & \multicolumn{2}{|c|}{5,398} & \multicolumn{2}{|c|}{4,953} \\
\hline \multicolumn{7}{|l|}{ Math } \\
\hline Conceived in Ramadan & -0.022 & $(0.113)$ & 0.129 & $(0.168)$ & -0.109 & $(0.174)$ \\
\hline First trimester & 0.071 & $(0.114)$ & -0.015 & $(0.172)$ & 0.130 & $(0.174)$ \\
\hline Second trimester & 0.051 & $(0.119)$ & 0.075 & $(0.176)$ & 0.128 & $(0.184)$ \\
\hline Third trimester & 0.077 & $(0.101)$ & 0.102 & $(0.151)$ & 0.044 & $(0.154)$ \\
\hline $\mathrm{N}$ & \multicolumn{2}{|c|}{11,108} & \multicolumn{2}{|c|}{5,739} & \multicolumn{2}{|c|}{5,369} \\
\hline \multicolumn{7}{|l|}{ Science } \\
\hline Conceived in Ramadan & -0.096 & $(0.125)$ & -0.126 & $(0.185)$ & 0.022 & $(0.192)$ \\
\hline First trimester & -0.138 & $(0.126)$ & -0.075 & $(0.190)$ & -0.094 & $(0.192)$ \\
\hline Second trimester & -0.018 & $(0.131)$ & -0.106 & $(0.193)$ & 0.107 & $(0.203)$ \\
\hline Third trimester & 0.113 & $(0.111)$ & -0.070 & $(0.164)$ & $0.302 *$ & $(0.168)$ \\
\hline $\mathrm{N}$ & \multicolumn{2}{|c|}{10,304} & \multicolumn{2}{|c|}{5,408} & \multicolumn{2}{|c|}{4,896} \\
\hline
\end{tabular}

Notes: Estimates refer to the coefficient on Muslim*(Ramadan Exposure). The omitted category includes persons who are classified as "Certainly not exposed to Ramadan in utero" The following control variables are included in the estimations but not shown: gender (in the sample incl. boys and girls), year of birth, month of birth, mother's age, mother's age squared, years since mother's migration, years since mother's migration squared, number of siblings, first born, mother married or cohabiting, mother's education $<9$ years of schooling, mothers education is not completed in Denmark, mother's employment status at age 15, log of gross family income, child's age at exam. Furthermore, we include mother's country of origin and school fixed effects. *, **, and $* * *$ indicate statistical significance at $10 \%, 5 \%$, and $1 \%$ levels, respectively. 
Table 5: Difference-in-Differences Estimate of the Effect of Fetal Exposure to Ramadan on Test Scores of Low-SES Muslim Students

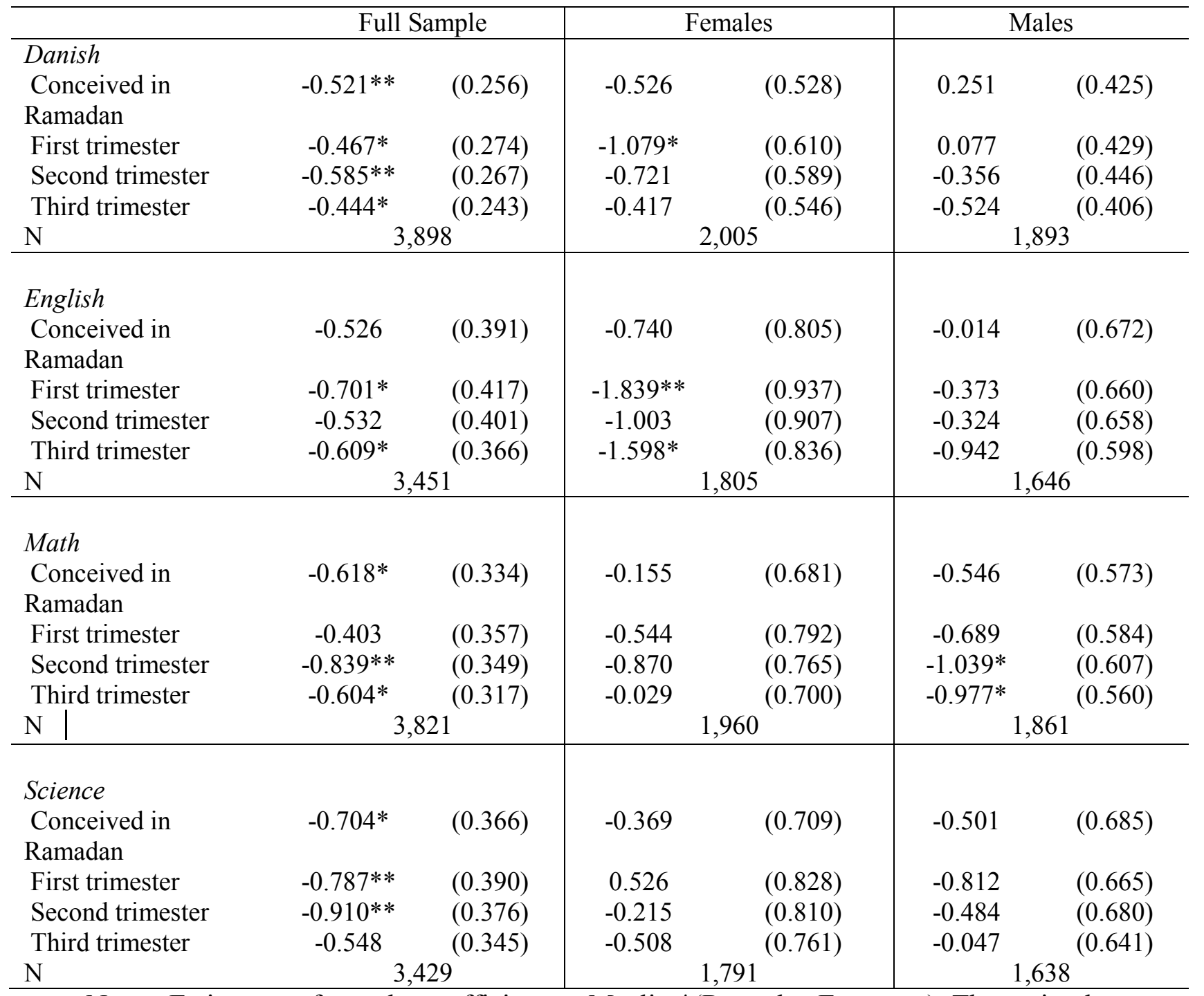

Notes: Estimates refer to the coefficient on Muslim*(Ramadan Exposure). The omitted category includes persons who are classified as "Certainly not exposed to Ramadan in utero" The following control variables are included in the estimations but not shown: gender (in the sample incl. boys and girls), year of birth, month of birth, mother's age, mother's age squared, years since mother's migration, years since mother's migration squared, number of siblings, first born, mother married or cohabiting, mother's education $<9$ years of schooling, mothers education is not completed in Denmark, mother's employment status at age $15, \log$ of gross family income, child's age at exam. Furthermore, we include mother's country of origin and school fixed effects. *, **, and $* * *$ indicate statistical significance at $10 \%, 5 \%$, and $1 \%$ levels, respectively. 
Appendix Table 1: Effects of Fetal Exposure to Ramadan on Test Scores of non-Muslim Students (Non-Muslim Sample Only)

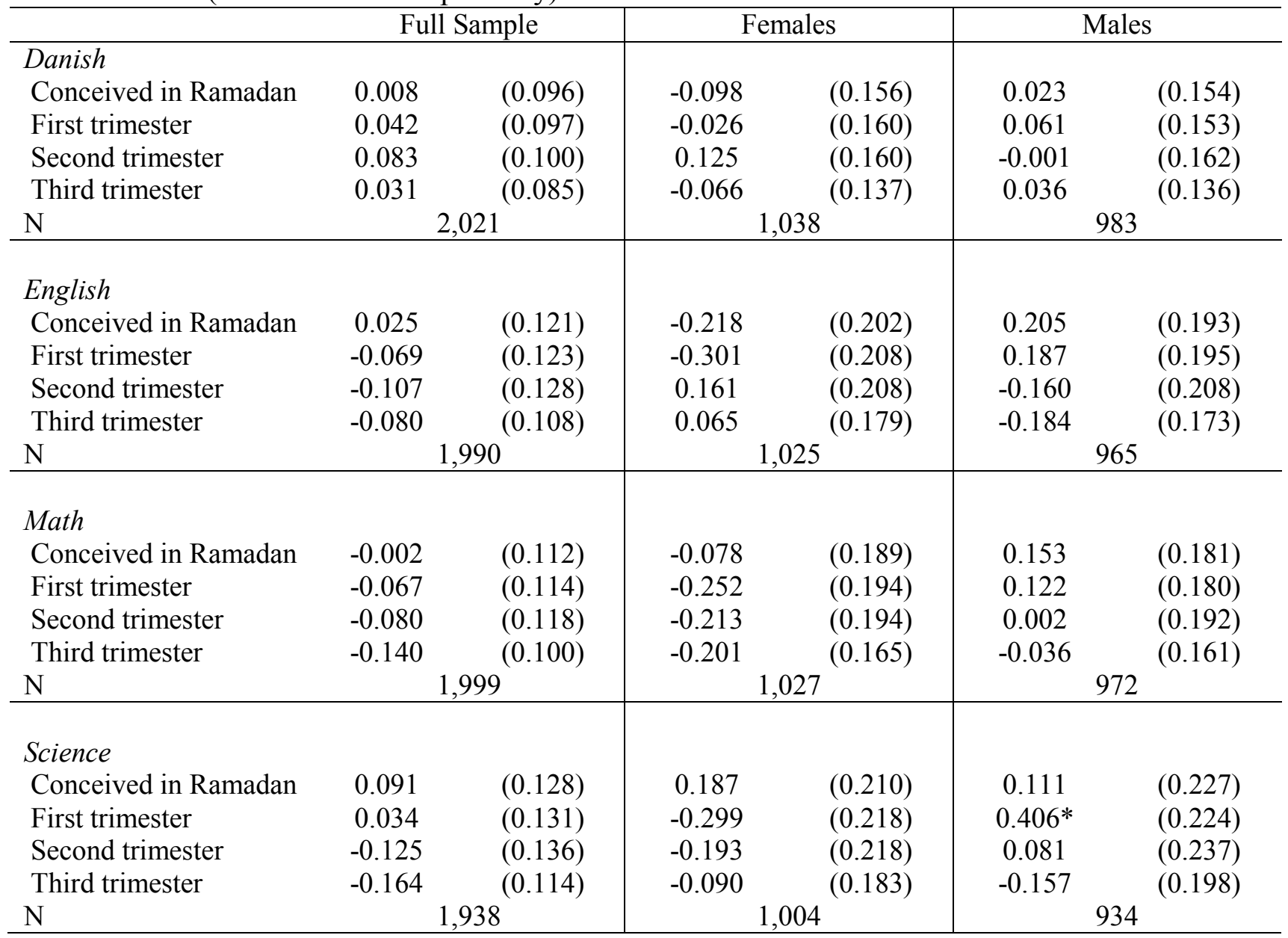

Notes: The omitted category includes persons who are classified as "Not exposed to Ramadan in utero" The following control variables are included in the estimations but not shown: gender (in the sample incl. boys and girls), year of birth, month of birth, mother's age, mother's age squared, years since mother's migration, years since mother's migration squared, number of siblings, first born, mother married or cohabiting, mother's education $<9$ years of schooling, mothers education is not completed in Denmark, mother's employment status at age $15, \log$ of gross family income, child's age at exam. Furthermore, we include mother's country of origin and school fixed effects. ${ }^{*}, * *$, and $* * *$ indicate statistical significance at $10 \%, 5 \%$, and $1 \%$ levels, respectively. 
Appendix Table 2: Difference-in-Differences Estimate of the Effect of Fetal Exposure to Ramadan on Test Scores of non-Low-SES Muslim Students

\begin{tabular}{|c|c|c|c|c|c|c|}
\hline & \multicolumn{2}{|c|}{ Full Sample } & \multicolumn{2}{|c|}{ Females } & \multicolumn{2}{|c|}{ Males } \\
\hline Danish & & & & & & \\
\hline Conceived in Ramadan & 0.047 & $(0.104)$ & -0.047 & $(0.159)$ & 0.119 & $(0.161)$ \\
\hline First trimester & -0.016 & $(0.104)$ & -0.242 & $(0.160)$ & 0.160 & $(0.158)$ \\
\hline Second trimester & 0.018 & $(0.109)$ & -0.038 & $(0.165)$ & 0.102 & $(0.167)$ \\
\hline Third trimester & 0.065 & $(0.092)$ & 0.062 & $(0.141)$ & 0.096 & $(0.138)$ \\
\hline $\mathrm{N}$ & \multicolumn{2}{|c|}{7,393} & \multicolumn{2}{|c|}{3,830} & \multicolumn{2}{|c|}{3,563} \\
\hline \multicolumn{7}{|l|}{ English } \\
\hline Conceived in Ramadan & 0.035 & $(0.146)$ & -0.128 & $(0.222)$ & 0.184 & $(0.224)$ \\
\hline First trimester & 0.025 & $(0.146)$ & -0.125 & $(0.224)$ & 0.039 & $(0.223)$ \\
\hline Second trimester & 0.088 & $(0.153)$ & -0.146 & $(0.230)$ & 0.214 & $(0.237)$ \\
\hline Third trimester & 0.097 & $(0.130)$ & -0.069 & $(0.197)$ & $0.331^{*}$ & $(0.196)$ \\
\hline $\mathrm{N}$ & \multicolumn{2}{|c|}{6,900} & \multicolumn{2}{|c|}{3,593} & \multicolumn{2}{|c|}{3,307} \\
\hline \multicolumn{7}{|l|}{ Math } \\
\hline Conceived in Ramadan & 0.104 & $(0.129)$ & 0.205 & $(0.190)$ & 0.023 & $(0.206)$ \\
\hline First trimester & 0.191 & $(0.128)$ & 0.011 & $(0.193)$ & 0.269 & $(0.203)$ \\
\hline Second trimester & $0.241 *$ & $(0.135)$ & 0.314 & $(0.198)$ & 0.307 & $(0.216)$ \\
\hline Third trimester & $0.196^{*}$ & $(0.114)$ & $0.286^{*}$ & $(0.168)$ & 0.165 & $(0.180)$ \\
\hline $\mathrm{N}$ & \multicolumn{2}{|c|}{7,287} & \multicolumn{2}{|c|}{3,779} & \multicolumn{2}{|c|}{3,508} \\
\hline \multicolumn{7}{|l|}{ Science } \\
\hline Conceived in Ramadan & 0.061 & $(0.143)$ & -0.075 & $(0.214)$ & 0.200 & $(0.228)$ \\
\hline First trimester & -0.015 & $(0.144)$ & -0.077 & $(0.217)$ & 0.068 & $(0.226)$ \\
\hline Second trimester & 0.130 & $(0.150)$ & 0.037 & $(0.223)$ & 0.240 & $(0.241)$ \\
\hline Third trimester & $0.229 *$ & $(0.127)$ & 0.080 & $(0.187)$ & $0.386^{*}$ & $(0.198)$ \\
\hline $\mathrm{N}$ & \multicolumn{2}{|c|}{6,875} & \multicolumn{2}{|c|}{3,617} & \multicolumn{2}{|c|}{3,258} \\
\hline
\end{tabular}

Notes: Estimates refer to the coefficient on Muslim*(Ramadan Exposure). The omitted category includes persons who are classified as "Not exposed to Ramadan in utero" The following control variables are included in the estimations but not shown: gender (in the sample incl. boys and girls), year of birth, month of birth, mother's age, mother's age squared, years since mother's migration, years since mother's migration squared, number of siblings, first born, mother married or cohabiting, mother's education $<9$ years of schooling, mothers education is not completed in Denmark, mother's employment status at age 15, log of gross family income, child's age at exam. Furthermore, we include mother's country of origin and school fixed effects. $*, * *$, and $* * *$ indicate statistical significance at $10 \%, 5 \%$, and $1 \%$ levels, respectively. 